\title{
Overall survival benefits of first-line EGFR tyrosine kinase inhibitors in EGFR-mutated non-small-cell lung cancers: a systematic review and meta-analysis
}

\begin{abstract}
Feng-Che Kuan ${ }^{1,2}$, Liang-Tseng Kuo ${ }^{3,4,5}$, Min-Chi Chen ${ }^{6}$, Cheng-Ta Yang ${ }^{7,8}$, Chung-Sheng Shi ${ }^{9}$, David Teng ${ }^{10}$ and Kuan-Der Lee ${ }^{*}, 1,11$

${ }^{1}$ Department of Hematology and Oncology, Chang-Gung Memorial Hospital, Chia-Yi 61363, Taiwan; ${ }^{2}$ Graduate Institute of Clinical Medical Sciences, Chang-Gung University, Tao-Yuan 33302, Taiwan; ${ }^{3}$ Department of Orthopaedic Surgery, Division of Sports Medicine, Chang-Gung Memorial Hospital, Chia-Yi, Taiwan; ${ }^{4}$ Centre for Evidence-Based Medicine, Chang-Gung Memorial Hospital, Chia-Yi, Taiwan; ${ }^{5}$ Chang-Gung University of Science and Technology, Chia-Yi, Taiwan; ${ }^{6}$ Department of Public Health, Biostatistics Consulting Center, College of Medicine, Chang-Gung University, Tao-Yuan, Taiwan; ${ }^{7}$ Department of Thoracic Medicine, Chang-Gung Memorial Hospital, Tao-Yuan 33305, Taiwan; ${ }^{8}$ Department of Respiratory Therapy, College of Medicine, Chang-Gung University, Tao-Yuan, Taiwan; ${ }^{9}$ Graduate Institute of Clinical Medical Sciences, College of Medicine, Chang-Gung University, Tao-Yuan, Taiwan; ${ }^{10}$ Department of Bioengineering, University of California, Los Angeles, California 94720, USA and ${ }^{11}$ Department of Medicine, Chang-Gung University, Tao-Yuan, Taiwan
\end{abstract}

Background: Accumulating data shows that exon 19 deletions and L858R, both activating epidermal growth factor receptor mutations in non-small-cell lung cancers (NSCLCs), are just two different entities in terms of prognosis and treatment response to tyrosine kinase inhibitors (TKIs).

Methods: A systematic review and meta-analysis of randomized controlled trials comparing TKls with conventional chemotherapy was performed. Eight trials of 1498 patients and five trials of 1279 patients with either exon 19 deletions or L858R were included in the meta-analysis.

Results: TKI treatment demonstrated progression-free survival benefit in patients with exon 19 deletions (hazard ratio (HR): 0.27 , 95\% confidence interval (Cl): 0.21-0.35) and L858R (HR: 0.45,95\% Cl: 0.35-0.58). Patients with exon 19 deletions had significant overall survival (OS) benefit under TKI treatment (HR: 0.72, 95\% Cl: 0.60-0.88). Subgroup analyses showed that irreversible TKIs, but not reversible TKIs, had statistically significant OS benefit in these patients (irreversible TKIs, HR: 0.59, 95\% Cl: 0.47-0.73; reversible TKIs, HR: 0.84, 95\% Cl: 0.69-1.02). Patients with L858R demonstrated no OS benefit under first-line TKI use (HR: 1.15, 95\% Cl: 0.95-1.39).

Conclusions: In patients with advanced NSCLC harbouring exon 19 deletions, TKls are associated with better OS compared with conventional chemotherapy. Future clinical trials should take exon 19 deletions and L858R as distinct disease entities and evaluate the treatment efficacy separately.

*Correspondence: Professor K-D Lee; E-mail: kdlee@cgmh.org.tw

Received 8 May 2015; revised 5 September 2015; accepted 14 September 2015; published online 13 October 2015 (c) 2015 Cancer Research UK. All rights reserved 0007-0920/15 
Personalised medicine has an important role in the treatment of lung cancer, which accounts for $18 \%$ of all cancer-related death worldwide (GLOBOCAN, 2008). Activation of the epidermal growth factor receptor (EGFR) pathway is associated with the promotion of tumor growth, invasion, and metastasis, and the inhibition of apoptosis (Lynch et al, 2004; Paez et al, 2004; Hirsch and Bunn, 2009). In non-small-cell lung cancers (NSCLCs), EGFR-activating mutations include deletions in exon 19 ( $\sim 45 \%)$, substitution of leucine-858 with arginine (L858R) in exon $21(\sim 45 \%)$ and other rare mutations (Sharma et al, 2007). Tyrosine kinase inhibitors (TKIs) like gefitinib (Mok et al, 2009; Maemondo et al, 2010; Mitsudomi et al, 2010; Fukuoka et al, 2011; Zhou et al, 2011; Han et al, 2012; Inoue et al, 2013), erlotinib (Rosell et al, 2012, Zhou et al, 2012; Wu et al, 2013), and afatinib (Sequist et al, 2013; Wu et al, 2014) target such mutations and confer remarkable response rate (RR) and PFS when compared with conventional chemotherapy in several randomized controlled trials (RCTs). However, no single RCT (Mok et al, 2009; Maemondo et al, 2010; Mitsudomi et al, 2010; Fukuoka et al, 2011; Zhou et al, 2011; Mitsudomi et al, 2012; Zhou et al, 2012; Han et al, 2012; Rosell et al, 2012; Inoue et al, 2013; Sequist et al, 2013; Wu et al, 2013, 2014) or meta-analysis (Lee et al, 2013; Haaland et al, 2014; Liang et al, 2014; Paz-Ares et al, 2014) shows overall survival (OS) benefits from TKIs.

In some retrospective studies (Lu et al, 2014; Skrickova et al, 2014) and meta-analyses (Wang et al, 2014; Zhang et al, 2014), patients with L858R seem to have poorer PFS (Rosell et al, 2012; Kato et al, 2014; Ichihara et al, 2015) and OS (Sequist et al, 2013; Wu et al, 2014) than those with exon 19 deletions. In several pre-clinical studies, lung cancer cell lines with exon 19 deletions or L858R have different sensitivities to reversible TKIs (gefitinib and erlotinib) and irreversible TKI (afatinib; Li et al, 2008; Furuyama et al, 2013; Cross et al, 2014). It may be posited that NSCLC harbouring exon 19 deletions and L858R may represent two distinct entities of lung adenocarcinoma. To validate this issue, a meta-analysis of current RCTs was performed by separating patients who received three different TKIs (gefitinib, erlotinib, and afatinib) into exon 19 deletions and L858R EGFR mutations.

\section{MATERIALS AND METHODS}

Data source and search strategy. A comprehensive search to identify all published RCTs that compared the outcomes of TKI vs chemotherapy for NSCLC was done. MEDLINE, EMBASE, and the Cochrane Central Register of Controlled Trials (CENTRAL) were searched for relevant trials from inception to 31 January 2015. The search strategy was a combination of the terms 'EGFR', 'epidermal growth factor receptor', 'tyrosine kinase inhibitors', 'TKI', 'exon', 'mutation', 'non-small-cell lung cancer', and 'NSCLC' without restrictions on language and gender. Additional searches through Google Scholar and the United States National Institutes of Health trials register (http://clinicaltrial.gov), and a manual search through reference lists of pertinent reviews and studies were performed. Two authors conducted the search independently with no language or date restrictions set. Lastly, a pharmaceutical company (F. Hoffmann-La Roche Ltd) was contacted for information on unpublished trials.

Inclusion and exclusion criteria. Eligible studies should meet the following criteria:

(1) Clinical trials that investigated local advanced or metastatic (IIIB or IV) stage NSCLC with first-line monotherapy of EGFR-TKIs.

(2) Clinical trials with a subset of NSCLC patients with specific EGFR mutation (exon 19 deletions or L858R).
(3) EGFR mutation analysis was performed on available tumor tissue samples instead of circulating free DNA in serum.

(4) Prior neo-adjuvant or adjuvant chemotherapy in patients with recurrence after surgery if there was at least 6 months from the last administration to the relapse.

(5) HRs of EGFR-TKIs compared with conventional chemotherapy for PFS and OS, and HRs of exon 19 deletions compared with L858R for PFS in terms of EGFR-TKIs were available.

Studies that did not meet these criteria were excluded.

Selection of studies. Duplicate records of the search results were removed. The two review authors, who were not blinded to the names of original researchers, journals, or institutions, independently checked the titles, abstracts, and keywords from the searches to identify potentially eligible studies. Upon obtaining the full texts of potentially eligible trials, the same two review authors performed an independent study selection and disagreements were resolved by consensus and, if necessary, by consult with a third reviewer.

Data extraction and quality assessment. Two authors independently extracted data using a standardized collection process that included first author, year of publication, intervention type, study population per group, study design (patient selection and concealment), clinical settings (doses and routes of TKI and chemotherapy), and outcomes (progression-free survival (PFS) and OS).

The Cochrane Collaboration tool was used to assess risk of bias for each trial (Higgins and Green, 2008). Seven domains associated with biased estimates of treatment effect (i.e., random sequence generation, allocation concealment, blinding of participant and personnel, blinding of outcome assessment, incomplete outcome data, selective reporting, and other biases) were evaluated. A third author resolved the differences in opinions.

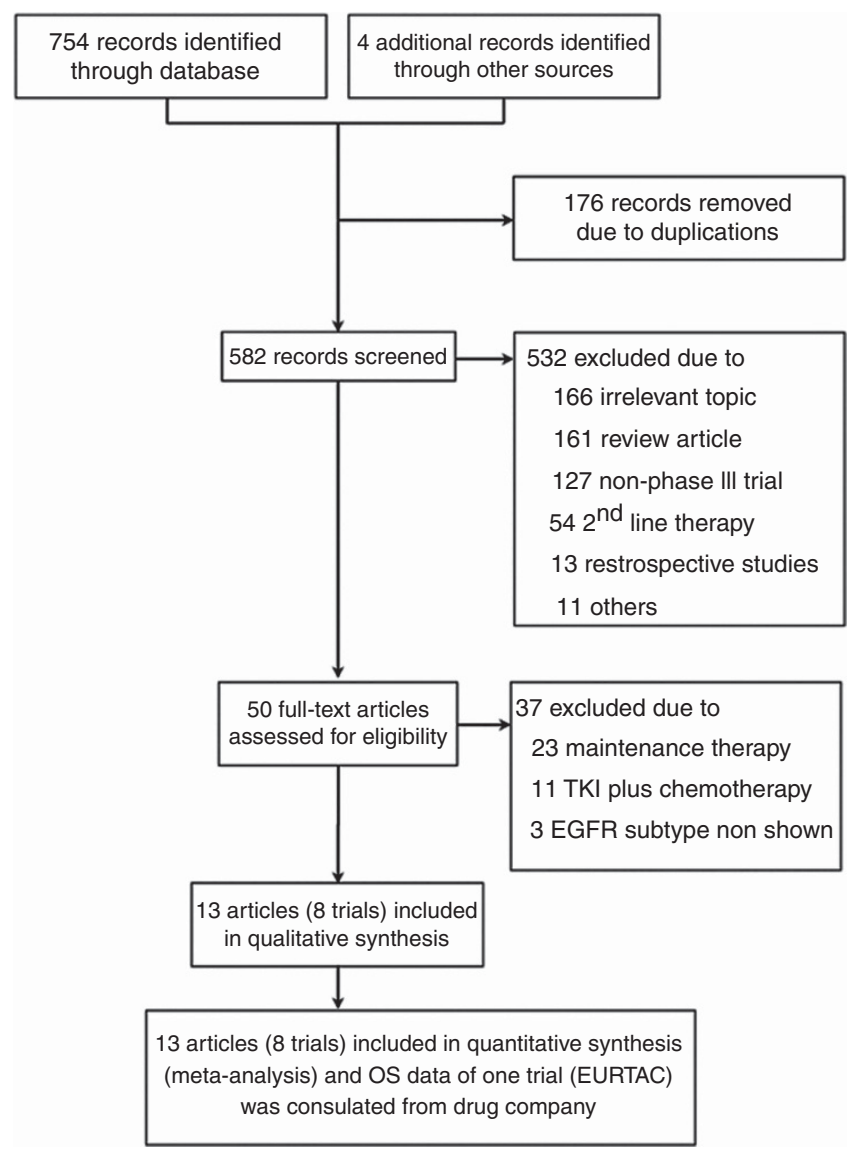

Figure 1. The trial selection process. 
Table 1. Characteristics of included trials for meta-analysis for PFS

\begin{tabular}{|c|c|c|c|c|c|c|}
\hline Lead author (year) & $\begin{array}{l}\text { Trial name } \\
\text { (phase) }\end{array}$ & TKI & Chemotherapy & $\begin{array}{c}\text { EGFR } \\
\text { mutation }\end{array}$ & $\begin{array}{c}\text { Sample size } \\
\text { (TKI/ } \\
\text { chemotherapy) }\end{array}$ & $\begin{array}{l}\text { HR for PFS } \\
\quad(\text { TKI vs } \\
\text { chemotherapy) } \\
\text { mean }(95 \% \mathrm{Cl})\end{array}$ \\
\hline Mok et al (2009) & IPASS (III) & Gefitinib $250 \mathrm{mg}$ per day & $\begin{array}{l}\text { Carboplatin (AUC }=5 \text { or } 6) \\
\text { Paclitaxel }\left(200 \mathrm{mg} \mathrm{m}^{-2} \text { ) every }\right. \\
3 \text { weeks for } \leqslant 6 \text { cycles }^{\text {a }}\end{array}$ & $\begin{array}{l}\text { Del } 19 \\
\text { L858R }\end{array}$ & $\begin{array}{l}\text { Not available } \\
\text { Not available }\end{array}$ & $\begin{array}{l}0.38(0.26-0.56) \\
0.55(0.35-0.87)\end{array}$ \\
\hline Maemondo et al (2010) & NEJ002 (III) & Gefitinib $250 \mathrm{mg}$ per day & $\begin{array}{l}\text { Carboplatin }(A \cup C=6) \\
\text { Paclitaxel }\left(200 \mathrm{mg} \mathrm{m}^{-2}\right) \text { every } \\
3 \text { weeks for } \geqslant 3 \text { cycles }\end{array}$ & $\begin{array}{l}\text { Del } 19 \\
\text { L858R }\end{array}$ & $\begin{array}{l}58 / 59 \\
49 / 48\end{array}$ & $\begin{array}{l}0.35(0.23-0.52) \\
0.32(0.20-0.50)\end{array}$ \\
\hline $\begin{array}{l}\text { Mitsudomi et al (2010, } \\
\text { 2012) }\end{array}$ & WJTOG3405 (III) & Gefitinib $250 \mathrm{mg}$ per day & $\begin{array}{l}\text { Cisplatin }\left(80 \mathrm{mg} \mathrm{m}^{-2}\right) \\
\text { Docetaxel }\left(60 \mathrm{mg} \mathrm{m}^{-2}\right) \text { every } \\
3 \text { weeks for } 3 \text { to } 6 \text { cycles }\end{array}$ & $\begin{array}{l}\text { Del } 19 \\
\text { L858R }\end{array}$ & $\begin{array}{l}50 / 37 \\
36 / 49\end{array}$ & $\begin{array}{l}0.45(0.27-0.77) \\
0.51(0.29-0.90)\end{array}$ \\
\hline Zhou et al $(2011,2012)$ & OPTIMAL (III) & Erlotinib $150 \mathrm{mg}$ per day & $\begin{array}{l}\text { Carboplatin }(A \cup C=5) \text { on day } 1 \\
\text { Gemcitabine }\left(1000 \mathrm{mg} \mathrm{m}^{-2}\right) \text { on day } 1 \text { and } \\
8 \text {, every } 3 \text { weeks for } 4 \text { cycles }\end{array}$ & $\begin{array}{l}\text { Del } 19 \\
\text { L858R }\end{array}$ & $\begin{array}{l}43 / 39 \\
39 / 33\end{array}$ & $\begin{array}{l}0.13(0.07-0.25) \\
0.26(0.14-0.49)\end{array}$ \\
\hline Rosell et al (2012) & EURTAC (III) & Erlotinib $150 \mathrm{mg}$ per day & $\begin{array}{l}\text { Cisplatin }\left(75 \mathrm{mg} \mathrm{m}^{-2}\right) \text { on day } 1 \\
\text { Docetaxel }\left(75 \mathrm{mg} \mathrm{m}^{-2}\right) \text { on day } 1 \text { or } \\
\text { gemcitabine }\left(1250 \mathrm{mg} \mathrm{m}^{-2}\right) \text { on day } 1 \text { and } \\
8 \text {, every } 3 \text { weeks for } 4 \text { cycles }^{\text {b }}\end{array}$ & $\begin{array}{l}\text { Del } 19 \\
\text { L858R }\end{array}$ & $\begin{array}{l}57 / 58 \\
29 / 29\end{array}$ & $\begin{array}{l}0.30(0.18-0.50) \\
0.55(0.29-1.02)\end{array}$ \\
\hline Wu et al (2013) & EUSURE (III) & Erlotinib $150 \mathrm{mg}$ per day & $\begin{array}{l}\text { Cisplatin }\left(75 \mathrm{mg} \mathrm{m}^{-2}\right) \text { on day } 1 \\
\text { Gemcitabine }\left(1250 \mathrm{mg} \mathrm{m}^{-2}\right) \text { on day } 1 \text { and } \\
8 \text {, every } 3 \text { weeks for } \\
4 \text { cycles }\end{array}$ & $\begin{array}{l}\text { Del } 19 \\
\text { L858R }\end{array}$ & $\begin{array}{l}\text { Not available } \\
\text { Not available }\end{array}$ & $\begin{array}{l}0.20(0.12-0.33) \\
0.54(0.32-0.90)\end{array}$ \\
\hline Sequist et al (2013) & LUX-Lung 3 (III) & Afatinib $40 \mathrm{mg}$ per day & $\begin{array}{l}\text { Cisplatin }\left(75 \mathrm{mg} \mathrm{m}^{-2}\right) \\
\text { Pemetrexed }\left(500 \mathrm{mg} \mathrm{m}^{-2}\right) \text { every } 3 \text { weeks } \\
\text { for } \leqslant 6 \text { cycles }\end{array}$ & $\begin{array}{l}\text { Del } 19 \\
\text { L858R }\end{array}$ & $\begin{array}{c}112 / 57 \\
91 / 47\end{array}$ & $\begin{array}{l}0.28(0.18-0.44) \\
0.73(0.46-1.17)\end{array}$ \\
\hline Wu et al (2014) & LUX-Lung 6 (III) & Afatinib $40 \mathrm{mg}$ per day & $\begin{array}{l}\text { Cisplatin }\left(75 \mathrm{mg} \mathrm{m}^{-2}\right) \text { on day } 1 \\
\text { Docetaxel }\left(75 \mathrm{mg} \mathrm{m}^{-2}\right) \text { on day } 1 \text { or } \\
\text { gemcitabine }\left(1000 \mathrm{mg} \mathrm{m}^{-2}\right) \text { on day } 1 \text { and } \\
8 \text {, every } 3 \text { weeks for } \leqslant 6 \text { cycles }\end{array}$ & $\begin{array}{l}\text { Del } 19 \\
\text { L858R }\end{array}$ & $\begin{array}{c}124 / 62 \\
92 / 46\end{array}$ & $\begin{array}{l}0.20(0.13-0.33) \\
0.32(0.19-0.52)\end{array}$ \\
\hline \multicolumn{7}{|c|}{ 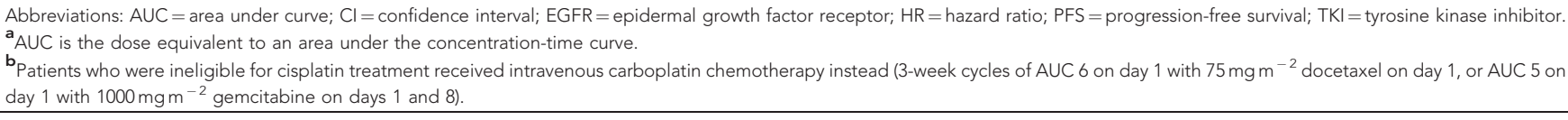 } \\
\hline
\end{tabular}

Statistical analysis. The Review Manager 5.3 (Review Manager, 2014) was used for meta-analysis. Pooled HRs for PFS and OS with 95\% confidence intervals (CIs) were calculated. A random-effects (RE) model was used to calculate pooled HRs or relative risks, $95 \%$ CIs, and values. A generic inverse variance meta-analysis was performed by using log hazard ratio and its standard error. If the hazard ratio is quoted in a report together with a CI or $P$-value, estimates of standard error can be obtained as described in Cochrane Handbook (Higgins and Green, 2008). Statistical significance was set at a two-sided $P<0.05$.

For heterogeneity tests, $\chi^{2}$ tests and $I^{2}$ inconsistency statistics (Higgins and Thompson, 2002; Higgins et al, 2003) were used. A $P$-value of $<0.10$ was considered significant heterogeneity. $I^{2}$ values of $0-24.9 \%, 25-49.9 \%, 50-74 \%$, and $75-100 \%$ were considered as none, low, moderate, and high heterogeneity, respectively (Higgins and Thompson, 2002; Higgins et al, 2003). The RE model was used for all outcomes because clinical heterogeneity could not be excluded (DerSimonian and Laird, 1986). A funnel plot method and the Egger test for asymmetry was also used to assess the potential of publication bias (Egger et al, 1997). A forest plot was applied for display of results.

\section{RESULTS}

Eligible studies. From 758 records identified according to the search strategy, 13 studies reported advanced NSCLC patients with either exon 19 deletions or L858R mutation who received first-line monotherapy of EGFR-TKIs. There were 8 phase III RCTs (IPASS (Mok et al, 2009; Fukuoka et al, 2011), NEJ002 (Maemondo et al, 2010; Inoue et al, 2013), WJTOG3405
(Mitsudomi et al, 2010, 2012), OPTIMAL (Zhou et al, 2011, 2012), (EURTAC, 2013) (Rosell et al, 2012), ENSURE (Wu et al, 2013), LUX-Lung 3 (Sequist et al, 2013; Yang et al, 2014, 2015), and LUX-Lung 6 (Wu et al, 2014; Yang et al, 2014, 2015) with 1498 advanced NSCLC chemo-naive patients that investigated the efficacy of EGFR-TKIs (gefitinib, erlotinib, or afatinib) and conventional chemotherapy. The PFS, OS, and subgroup analyses of different sensitive EGFR mutations were reported. Thus, these studies were included in the meta-analysis.

The Preferred Reporting Items for Systematic Reviews and Meta-Analyses (PRISMA) study flow diagram is shown in Figure 1, whereas Tables 1 and 2 summarize the characteristics of the included studies.

Risk of bias. All the included trials had a low risk of bias when appraised using the Cochrane Collaboration's tool (Egger et al, 1997; Figure 2).

PFS analysis. There were eight trials of 1498 patients with either exon 19 deletions or L858R in this analysis. The TKI treatment demonstrated consistent PFS benefits both in patients with exon 19 deletions (HR: 0.27, 95\% CI: 0.21-0.35) and L858R (HR: 0.45, 95\% CI: $0.35-0.58$; Figures $3 \mathrm{~A}$ and $4 \mathrm{~A}$, respectively).

Subgroup analyses of reversible (gefitinib and erlotinib) and irreversible (afatinib) TKIs revealed statistically significant PFS in patients with exon 19 deletions (reversible TKIs, HR: 0.28, 95\% CI: 0.20-0.40; irreversible TKI, HR: 0.24, 95\% CI: $0.17-0.33$; Figure 3A). Moreover, reversible TKIs also had significant PFS in patients with L858R (HR: 0.44, 95\% CI: 0.34-0.57; Figure 4A). However, L858R patients treated with irreversible TKI had only marginal PFS benefit (HR: 0.48, 95\% CI: 0.22-1.09; Figure 4A). 
Table 2. Characteristics of included trials for meta-analysis for OS

\begin{tabular}{|c|c|c|c|c|c|c|}
\hline Lead author (y) & $\begin{array}{l}\text { Trial name } \\
\text { (phase) }\end{array}$ & TKI & Chemotherapy & $\begin{array}{c}\text { EGFR } \\
\text { mutation }\end{array}$ & $\begin{array}{c}\text { Sample size } \\
\text { (TKI/ } \\
\text { chemotherapy) }\end{array}$ & $\begin{array}{l}\text { HR for OS } \\
\text { (TKI vs } \\
\text { chemotherapy) } \\
\text { mean }(95 \% \mathrm{Cl})\end{array}$ \\
\hline Fukuoka et al (2011) & IPASS (III) & Gefitinib $250 \mathrm{mg}$ per day & $\begin{array}{l}\text { Carboplatin }(\mathrm{AUC}=5 \text { or } 6) \\
\text { Paclitaxel }\left(200 \mathrm{mg} \mathrm{m}^{-2}\right) \text { every } 3 \text { weeks for } \\
\leqslant 6 \text { cycles }^{\mathrm{a}}\end{array}$ & $\begin{array}{l}\text { Del } 19 \\
\text { L858R }\end{array}$ & $\begin{array}{l}\text { Not available } \\
\text { Not available }\end{array}$ & $\begin{array}{l}0.79(0.54-1.15) \\
1.44(0.90-2.30)\end{array}$ \\
\hline Inoue et al (2013) & NEJ002 (III) & Gefitinib $250 \mathrm{mg}$ per day & $\begin{array}{l}\text { Carboplatin }(\mathrm{AUC}=6) \\
\text { Paclitaxel }\left(200 \mathrm{mg} \mathrm{m}^{-2}\right) \text { every } 3 \text { weeks for } \\
\geqslant 3 \text { cycles }\end{array}$ & $\begin{array}{l}\text { Del } 19 \\
\text { L858R }\end{array}$ & $\begin{array}{l}58 / 59 \\
49 / 48\end{array}$ & $\begin{array}{l}0.83(0.52-1.34) \\
0.82(0.49-1.38)\end{array}$ \\
\hline EURTAC (2013) & EURTAC (III) & Erlotinib $150 \mathrm{mg}$ per day & $\begin{array}{l}\text { Cisplatin }\left(75 \mathrm{mg} \mathrm{m}^{-2}\right) \text { on day } 1 \\
\text { Docetaxel }\left(75 \mathrm{mg} \mathrm{m}^{-2}\right) \text { on day } 1 \text { or } \\
\text { gemcitabine }\left(1250 \mathrm{mg} \mathrm{m}^{-2}\right) \text { on day } 1 \text { and } 8, \\
\text { every } 3 \text { weeks for } 4 \text { cycles }^{\text {b }}\end{array}$ & $\begin{array}{l}\text { Del } 19 \\
\text { L858R }\end{array}$ & $\begin{array}{l}57 / 58 \\
29 / 29\end{array}$ & $\begin{array}{l}0.94(0.57-1.54) \\
0.99(0.56-1.76)\end{array}$ \\
\hline Yang et al (2015) & LUX-Lung 3 (III) & Afatinib $40 \mathrm{mg}$ per day & $\begin{array}{l}\text { Cisplatin }\left(75 \mathrm{mg} \mathrm{m}^{-2}\right) \\
\text { Pemetrexed }\left(500 \mathrm{mg} \mathrm{m}^{-2}\right) \text { every } \\
3 \text { weeks for } \leqslant 6 \text { cycles }\end{array}$ & $\begin{array}{l}\text { Del } 19 \\
\text { L858R }\end{array}$ & $\begin{array}{l}112 / 57 \\
91 / 47\end{array}$ & $\begin{array}{l}0.54(0.36-0.79) \\
1.30(0.80-2.11)\end{array}$ \\
\hline Yang et al (2015) & LUX-Lung 6 (III) & Afatinib $40 \mathrm{mg}$ per day & $\begin{array}{l}\text { Cisplatin }\left(75 \mathrm{mg} \mathrm{m}^{-2}\right) \text { on day } 1 \\
\text { Docetaxel }\left(75 \mathrm{mg} \mathrm{m}^{-2}\right) \text { on day } 1 \text { or } \\
\text { gemcitabine }\left(1000 \mathrm{mg} \mathrm{m}^{-2}\right) \text { on day } 1 \text { and } 8 \text {, } \\
\text { every } 3 \text { weeks for } \leqslant 6 \text { cycles }\end{array}$ & $\begin{array}{l}\text { Del } 19 \\
\text { L858R }\end{array}$ & $\begin{array}{l}124 / 62 \\
92 / 46\end{array}$ & $\begin{array}{l}0.64(0.44-0.94) \\
1.22(0.81-1.83)\end{array}$ \\
\hline \multicolumn{7}{|c|}{ 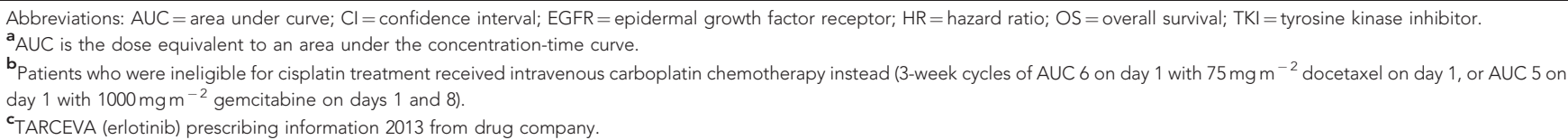 } \\
\hline
\end{tabular}

When stratified by chemotherapy (including cisplatin- or carboplatin-based regimen), both reversible and irreversible TKIs were associated with significant PFS in patients with exon 19 deletions (HR: 0.27, 95\% CI: 0.20-0.36) and L858R (HR: 0.44, 95\% CI: 0.33-0.58; Figures $3 \mathrm{~B}$ and $4 \mathrm{~B}$, respectively).

OS analysis. There were five trials of 1279 patients with either exon 19 deletions or L858R in this analysis. Patients with exon 19 deletions had significant OS benefits from TKI treatment (HR: 0.72, 95\% CI: 0.60-0.88; Figure 5A).

Subgroup analyses revealed that irreversible TKIs, but not reversible TKI, had statistically significant OS benefit in patients with exon 19 deletions (irreversible TKI, HR: 0.59, 95\% CI: 0.47-0.73; reversible TKIs, HR: 0.84, 95\% CI: 0.69-1.02; Figure 5A). But patients with L858R demonstrated no OS benefit regardless of the TKI used (HR: 1.15, 95\% CI: 0.95-1.39; Figure 6A).

When stratified between cisplatin- or carboplatin-based chemotherapy, TKI treatment was associated with significant OS benefits in patients with exon 19 deletions compared with those with cisplatin-based chemotherapy (cisplatin, HR: $0.59,95 \% \mathrm{CI}$ : 0.47-0.73; carboplatin, HR: 0.81, 95\% CI: 0.64-1.02; Figure 5B). In patients with L858R, TKI treatment showed no OS benefit over cisplatin- or carboplatin-based chemotherapy (HR: 1.18, 95\% CI: 0.94-1.48; Figure 6B). The HRs for all of the different comparisons are summarised in Table 3.

\section{DISCUSSION}

Previous RCTs (Mok et al, 2009; Maemondo et al, 2010; Mitsudomi et al, 2010; Fukuoka et al, 2011; Zhou et al, 2011; Mitsudomi et al, 2012; Zhou et al, 2012; Han et al, 2012; Rosell et al, 2012; Inoue et al, 2013; Sequist et al, 2013; Wu et al, 2013, 2014) did not show any OS benefits for TKIs in patients harbouring EGFR mutations as compared with those undergoing chemotherapy. Other meta-analyses of treatment with TKIs demonstrate only RR and PFS benefits, but no OS benefit, in a

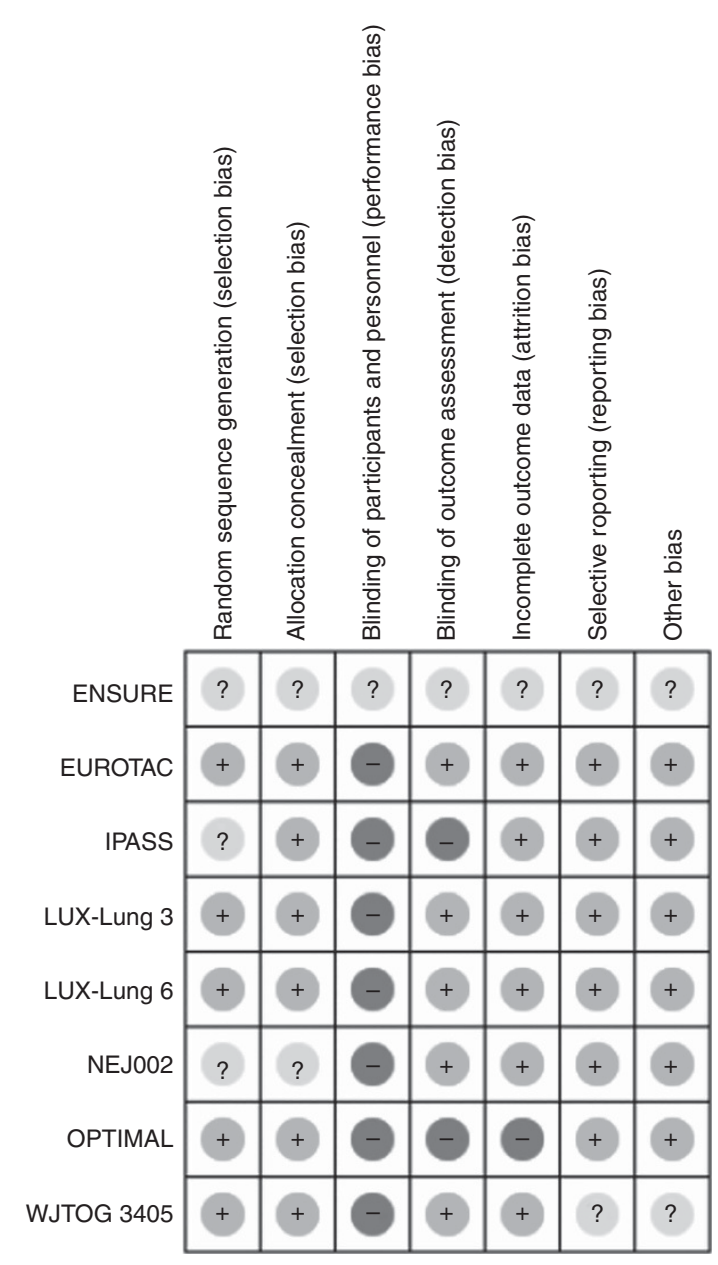

Figure 2. The risk of bias summary or review of judgments on each risk of bias item for each included study. 
A

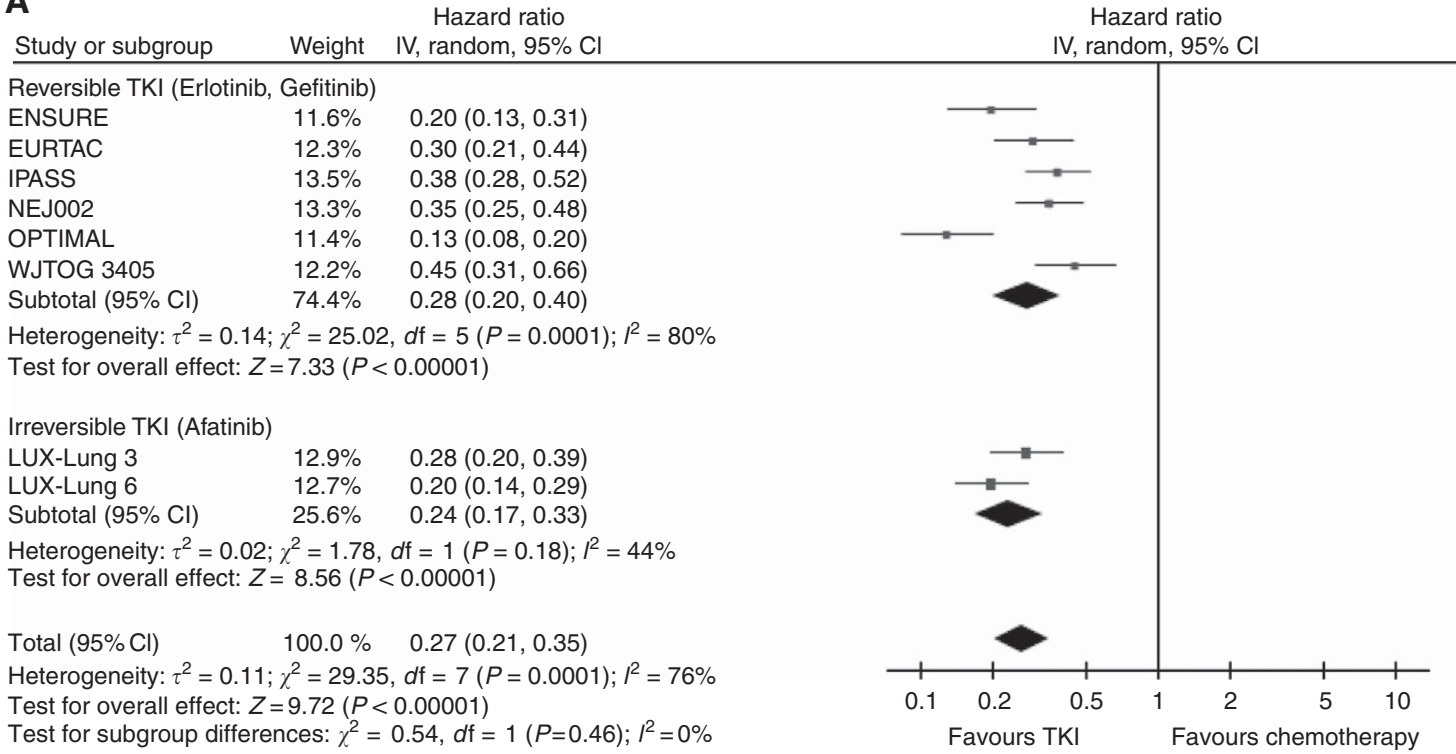

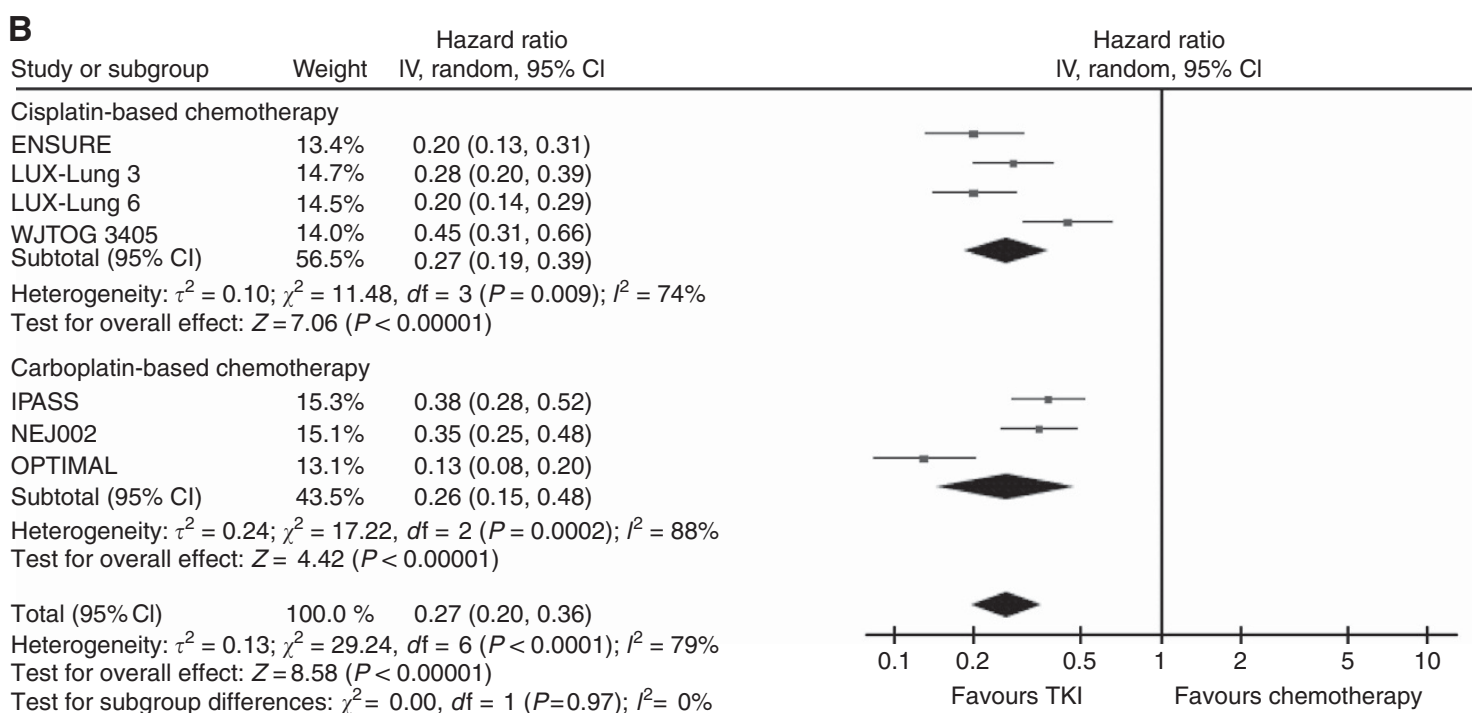

Figure 3. Progression-free survival analysis in exon 19 deletion tumours. (A) PFS analysis in exon 19 deletion tumours receiving reversible and irreversible TKIs. Pooled analysis showed significant PFS benefits in both reversible and irreversible TKIs. (B) PFS analysis in exon 19 deletion tumours receiving cisplatin- and carboplatin-based chemotherapy. Pooled analysis showed significant PFS benefit towards TKI treatment in both cisplatin- and carboplatin-based chemotherapy. Squares indicate study-specific HRs (size of the square reflects the study-specific statistical weight); horizontal lines indicate $95 \% \mathrm{Cl}$; diamond indicates the summary $\mathrm{HR}$ estimate with its $95 \% \mathrm{Cl}$.

population of mixed EGFR-activating mutations (Lee et al, 2013; Haaland et al, 2014; Liang et al, 2014). Recently, (Yang et al, 2014, 2015) reported on the OS benefits of afatinib, an irreversible TKI in patients with pooled data from LUX-lung 3 (Sequist et al, 2013) and 6 (Wu et al, 2014). Although afatinib is theoretically more effective in inhibiting EGFR signalling than reversible TKIs by forming permanent covalent bonds and irreversibly inhibiting ATP binding at the tyrosine kinase domain (Kosaka et al, 2011), no RCT and meta-analysis has shown that afatinib is superior to gefinitib or erlotinib in OS benefit. The present meta-analysis incorporates not only RCTs of afatinib but also other currently updated RCTs, including reversible TKIs like gefitinib and erlotinib. Our study reveals significant OS benefits of TKI treatment in patients with exon 19 deletions (HR: $0.72,95 \%$ CI: $0.60-0.88$ ) but not in those with L858R (HR: 1.15, 95\% CI: 0.95-1.39).

Patients with exon 19 deletions and L858R are separated in this analysis in view of their differing nature, based on previous literature (Sekine et al, 2012; Kato et al, 2014; Lu et al, 2014;
Skrickova et al, 2014; Wang et al, 2014; Ichihara et al, 2015). This study makes it possible to indirectly compare the efficacy of reversible and irreversible TKIs despite head-to-head RCTs are lacking in such patients. In this study, reversible TKIs demonstrate marginal OS benefits over conventional chemotherapy (HR: 0.84, 95\% CI: 0.69-1.02), which is the first to be seen in such a largescale meta-analysis. In addition, subgroup analysis of comparator chemotherapy discloses consistent OS benefit of TKI treatment irrespective of cisplatin- or carboplatin-based chemotherapy (HR: $0.68,95 \%$ CI: $0.57-0.83)$. On the basis of indirect comparison, the findings imply that both irreversible and reversible TKI treatments are associated with OS benefits in patients with exon 19 deletions. In order to compare the efficacy of irreversible and reversible TKIs, further head-to-head study, such as LUX-lung 7 (ClinicalTrials.gov Identifier NCT01466660) and ARCHER 1050 (ClinicalTrials.gov Identifier NCT01774721) are currently ongoing.

On the other hand, both irreversible and reversible TKIs are not associated with OS benefits in patients with L858R (HR: 1.15, 95\% 
A

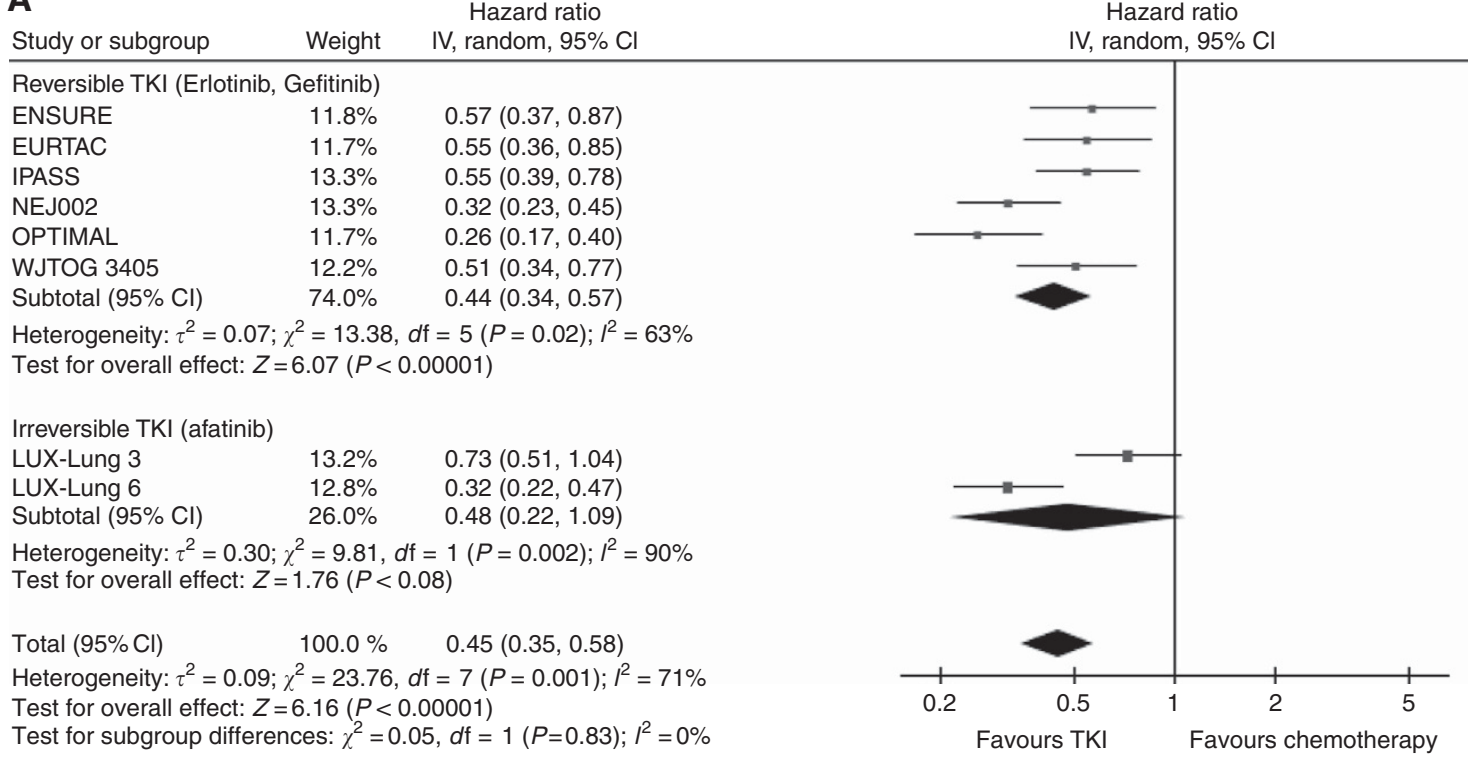

B

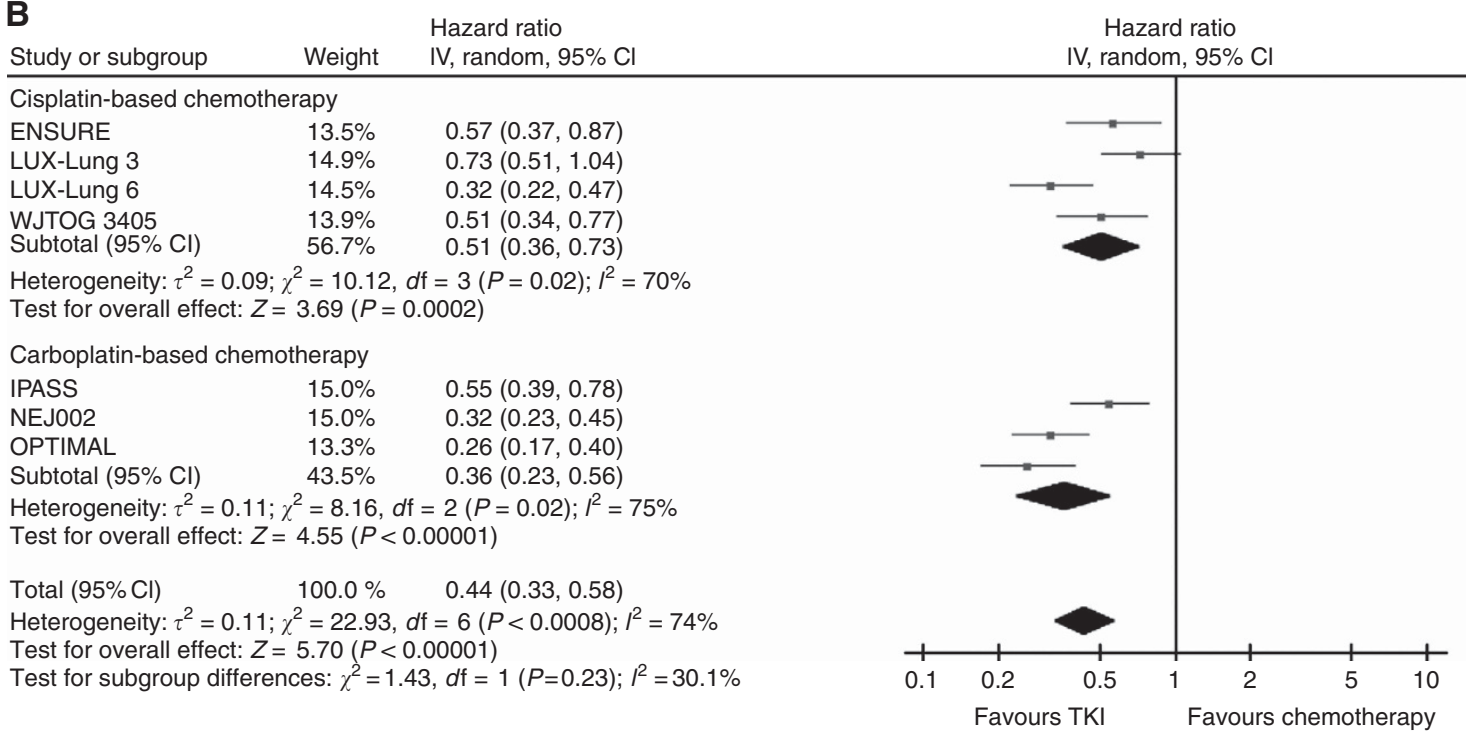

Figure 4. Progression-free survival analysis in L858R tumours. (A) PFS analysis in L858R tumours receiving reversible and irreversible TKIs. Pooled analysis showed significant PFS benefit only with reversible TKIs. (B) PFS analysis in L858R tumours receiving cisplatin- and carboplatinbased chemotherapy. Pooled analysis showed significant PFS benefit towards TKI treatment in both cisplatin- and carboplatin-based chemotherapy. Squares indicate study-specific HRs (size of the square reflects the study-specific statistical weight); horizontal lines indicate $95 \%$ $\mathrm{Cl}$; diamond indicates the summary $\mathrm{HR}$ estimate with its $95 \% \mathrm{Cl}$.

CI: 0.95-1.39), even with evident PFS benefits (HR: 0.45, 95\% CI: 0.35-0.58). This study adds updated WJTOG3405 and ENSURE trials, and consistent PFS benefit parallels previous literature in patients with L858R (Wang et al, 2014). Furthermore, subgroup analysis of comparator chemotherapy even suggests a trend in favor of chemotherapy (HR: 1.18, 95\% CI: 0.94-1.48), suggesting that first-line TKI may reduce sensitivity of chemotherapy in these patients, as proposed recently in a non-selection population (Zeng et al, 2014). Interestingly, in the subgroup analysis of PFS in patients with L858R, irreversible TKI demonstrates only marginal PFS benefit (HR: 0.48, 95\% CI: 0.22-1.09). The major impact may be because of the superior comparator chemotherapy of cisplatin/ pemetrexed in lung adenocarcinoma (Scagliotti et al, 2008).

In view of PFS in patients with exon 19 deletions, both reversible and irreversible TKIs are associated with significant benefits over cisplatin- or carboplatin-based chemotherapy (HR: 0.27, 95\% CI: $0.21-0.35)$. This also parallels the results of recent meta-analysis (Zhang et al, 2014). Updated WJTOG3405 and ENSURE trials are incorporated and subgroup analysis towards comparator chemotherapy shows no difference in various platinum-backbone combinations. Response towards TKI and platinum-based chemotherapy suggests that exon 19 deletions and L858R, though both are EGFR-activating mutations, have different disease nature towards treatment. This may be partly explained by a recent in vitro study (Furuyama et al, 2013), which reveals that EGFR-activating mutations have different sensitivities to gefitinib, erlotinib, and afatinib. A pre-clinical study also shows different acquired-resistance patterns of TKIs (Cross et al, 2014), even though a prospective re-biopsy protocol among patients with different EGFR-mutation who acquired resistance yields a similar presence of T790M mutation (Oxnard et al, 2011).

The L858R may form a complex with other uncommon mutations, such as G719S, which may affect hypersensitivity to TKIs (Chou et al, 2005; Mitsudomi and Yatabe, 2007; Wu et al, 
A

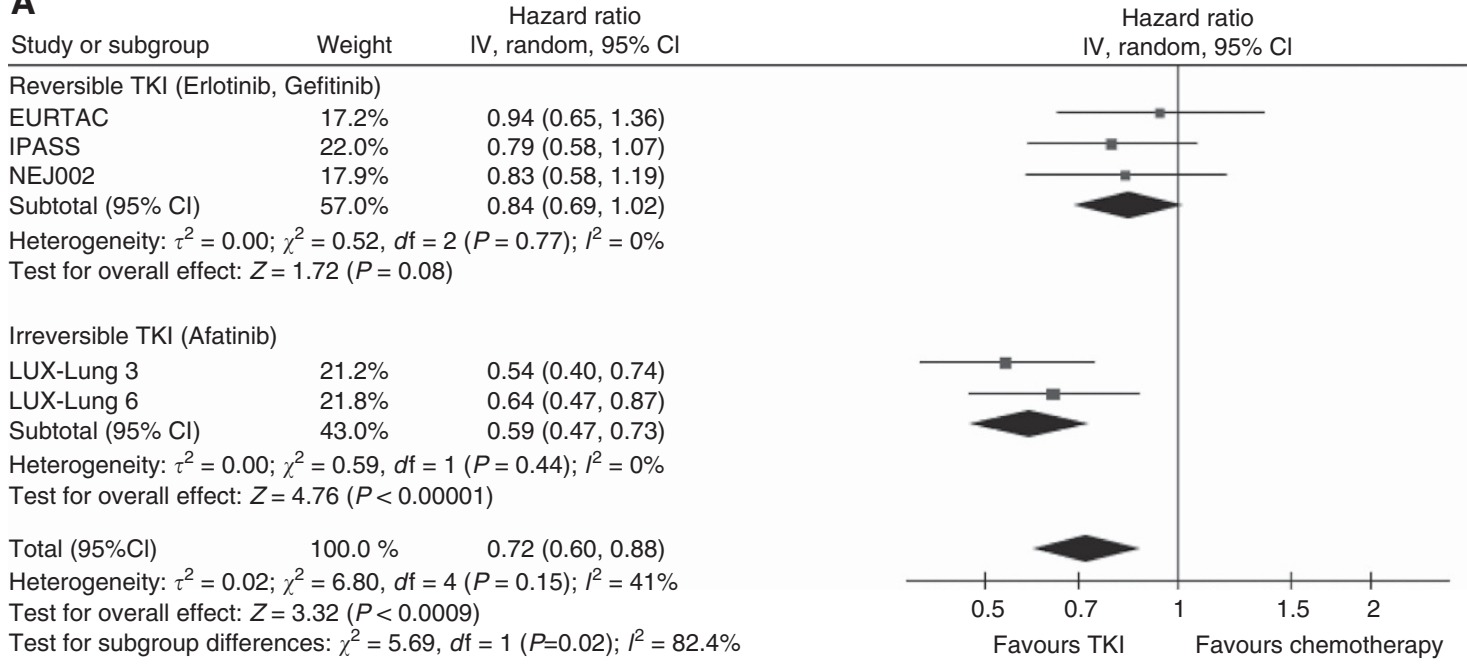

B

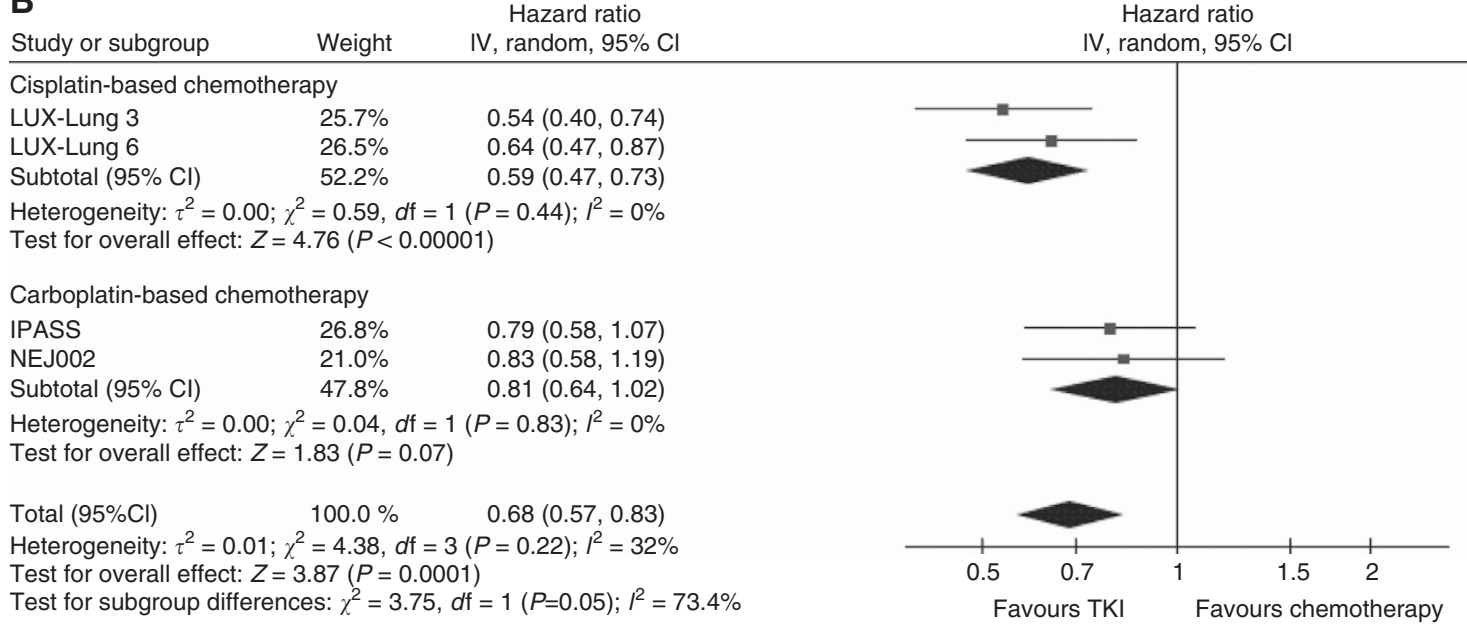

Figure 5. Overall survival analysis in exon 19 deletion tumours. (A) OS analysis in exon 19 deletion tumours receiving reversible and irreversible TKIs. Pooled analysis showed significant OS benefits only with irreversible TKIs. (B) OS analysis in exon 19 deletion tumours receiving cisplatin- and carboplatin-based chemotherapy. Pooled analysis showed significant OS benefit towards TKI treatment in cisplatin-based chemotherapy only. Squares indicate study-specific HRs (size of the square reflects the study-specific statistical weight); horizontal lines indicate $95 \% \mathrm{Cl}$; diamond indicates the summary HR estimate with its $95 \% \mathrm{Cl}$.

2008; Hata et al, 2010). Although the mechanism of more favourable efficacy of exon 19 deletions compared with L858R is still not well understood, they should be regarded as different diseases and clinical trials should report corresponding outcomes to individual EGFR mutations. Current guidelines put them into one category and suggest TKI treatment in both diseases, which is far from the aim of precision medicine in cancer treatment.

Nonetheless, this study had some limitations. First, the available clinical parameters, such as the HRs of PFS and OS in the subgroup of patients of several RCTs, were pooled together. This may compromise the evidence level owing to some differences in trial design, comparator choice, inclusion criteria, and reporting standards (Sebastian et al, 2014). Second, the OS would be confounded by the high proportion of patients crossing over into the alternative treatment and our trial was underpowered for assessment of such effect. From 39\% to 95\%, the patients allocated to chemotherapy were crossover-to-reversible TKIs (Mok et al, 2009; Maemondo et al, 2010; Inoue et al, 2013) and only LUX-lung 3 and 6 discretely reported $75 \%$ and $53 \%$ vs $74 \%$ and $61 \%$ of crossover-to-reversible TKIs but not afatinib (0-11\%; Yang et al, 2014). The crossover in RCTs powered for OS could not be assessed in view of exon 19 deletions and L858R. This is because the proportion of crossover is not reported separately for these activating mutations in trials regarding reversible TKIs. Third, this study attempted to address the OS difference in terms of comparator chemotherapy, but only four trials are eligible. The cisplatin-based chemotherapy is exactly paired with irreversible TKI, whereas carboplatin-based regimen is paired with reversible TKIs, which makes the interpretation of the OS difficult. Last, gefinitib and erlotinib are pooled in one category as reversible TKIs to overcome the problem of small number size of each drug. Previous literature indicates similar efficacy between these drugs (Gao et al, 2012; Yoshida et al, 2013; Katakami et al, 2014), but there is no first-line RCT for head-to-head comparison.

\section{CONCLUSIONS}

Accumulating evidence suggests that exon 19 deletions and L8585R are two different disease entities. Therapeutic strategies should differ when treating lung adenocarcinoma harbouring exon 19 deletions or L858R mutations. This study reveals that in patients with advanced NSCLC harbouring exon 19 deletions, both reversible and irreversible TKIs are associated with better OS 
A

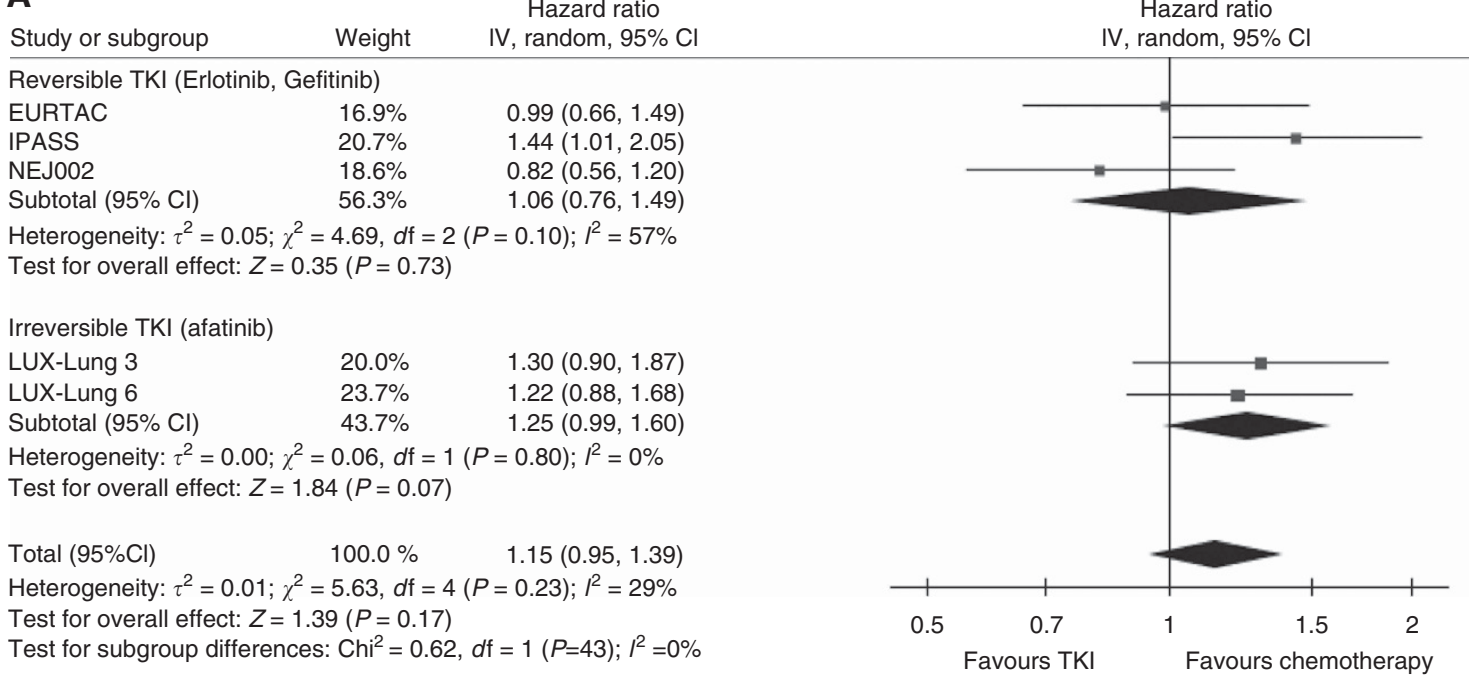

B

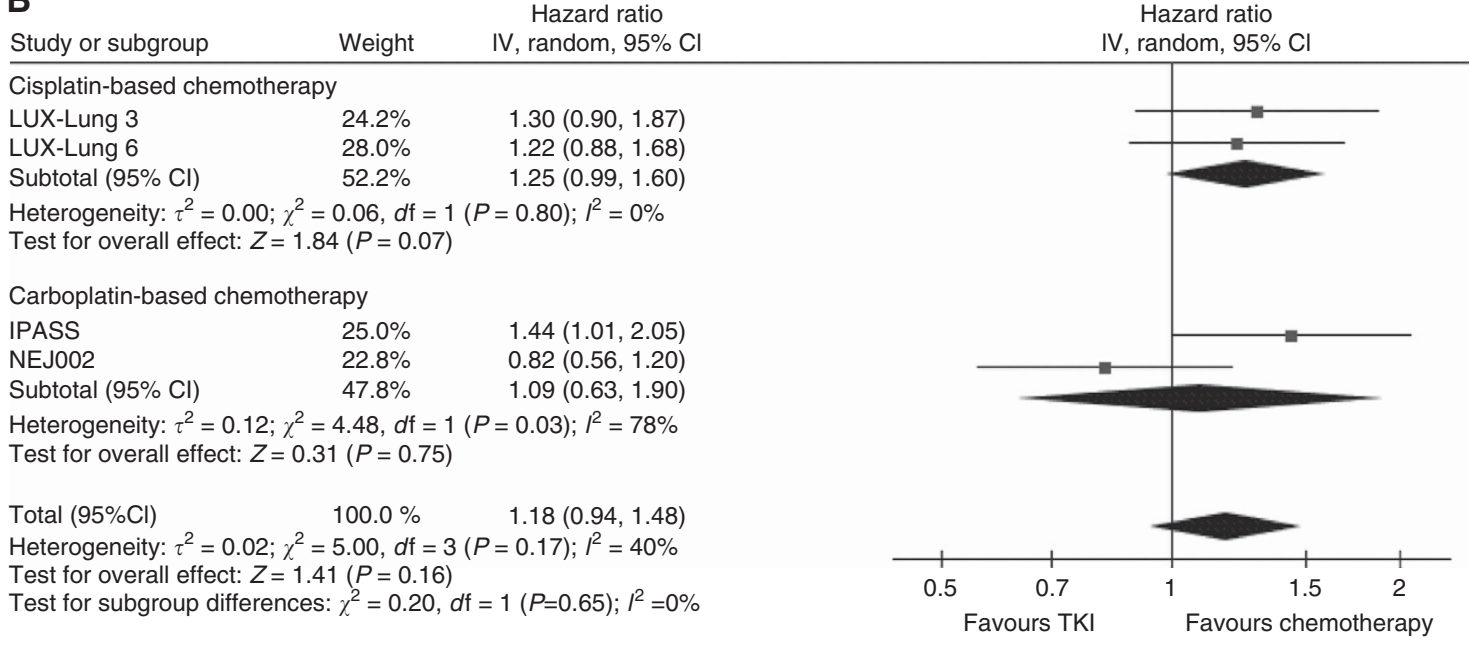

Figure 6. Overall survival analysis in L858R tumours. (A) OS analysis in L858R tumours receiving reversible and irreversible TKls. Pooled analysis showed no OS benefits with TKIs. (B) OS analysis in L858R tumours receiving cisplatin- and carboplatin-based chemotherapy. Pooled analysis showed no OS benefits towards TKI treatment in both cisplatin- and carboplatin-based chemotherapy. Squares indicate study-specific HRs (size of the square reflects the study-specific statistical weight); horizontal lines indicate $95 \% \mathrm{Cl}$; diamond indicates the summary $\mathrm{HR}$ estimate with its $95 \% \mathrm{Cl}$.

\begin{tabular}{|c|c|c|c|c|c|}
\hline Outcome & EGFR mutation & Subgroup & Studies & Statistical method & Effect estimate \\
\hline \multirow[t]{2}{*}{ PFS } & Deletion 19 & $\begin{array}{c}\text { Overall } \\
\text { Reversible TKI (erlotinib, gefitinib) } \\
\text { Irreversible TKI (afatinib) } \\
\text { TKI vs cisplatin-based chemotherapy } \\
\text { TKI vs carbiplatin-based chemotherapy }\end{array}$ & $\begin{array}{l}8 \\
6 \\
2 \\
4 \\
3\end{array}$ & $\begin{array}{l}\text { Hazard ratio (IV, random, 95\% Cl) } \\
\text { Hazard ratio (IV, random, 95\% Cl) } \\
\text { Hazard ratio (IV, random, 95\% Cl) } \\
\text { Hazard ratio (IV, random, 95\% Cl) } \\
\text { Hazard ratio (IV, random, 95\% Cl) }\end{array}$ & $\begin{array}{l}0.27(0.21-0.35) \\
0.28(0.20-0.40) \\
0.24(0.17-0.33) \\
0.27(0.19-0.39) \\
0.26(0.15-0.48)\end{array}$ \\
\hline & L858R & $\begin{array}{c}\text { Overall } \\
\text { Reversible TKI (erlotinib, gefitinib) } \\
\text { Irreversible TKI (afatinib) } \\
\text { TKI vs cisplatin-based chemotherapy } \\
\text { TKI vs carbiplatin-based chemotherapy }\end{array}$ & $\begin{array}{l}8 \\
6 \\
2 \\
4 \\
3\end{array}$ & $\begin{array}{l}\text { Hazard ratio (IV, random, 95\% Cl) } \\
\text { Hazard ratio (IV, random, 95\% Cl) } \\
\text { Hazard ratio (IV, random, } 95 \% \mathrm{CI}) \\
\text { Hazard ratio (IV, random, } 95 \% \mathrm{Cl}) \\
\text { Hazard ratio (IV, random, } 95 \% \mathrm{CI} \text { ) }\end{array}$ & $\begin{array}{l}0.45(0.35-0.58) \\
0.44(0.34-0.57) \\
0.48(0.22-1.09) \\
0.51(0.36-0.73) \\
0.36(0.23-0.56)\end{array}$ \\
\hline \multirow[t]{2}{*}{ OS } & Deletion 19 & $\begin{array}{c}\text { Overall } \\
\text { Reversible TKI (erlotinib, gefitinib) } \\
\text { Irreversible TKI (afatinib) } \\
\text { TKI vs cisplatin-based chemotherapy } \\
\text { TKI vs carbiplatin-based chemotherapy }\end{array}$ & $\begin{array}{l}5 \\
3 \\
2 \\
2 \\
2\end{array}$ & $\begin{array}{l}\text { Hazard ratio (IV, random, 95\% Cl) } \\
\text { Hazard ratio (IV, random, 95\% Cl) } \\
\text { Hazard ratio (IV, random, 95\% Cl) } \\
\text { Hazard ratio (IV, random, 95\% Cl) } \\
\text { Hazard ratio (IV, random, 95\% Cl) }\end{array}$ & $\begin{array}{l}0.72(0.60-0.88) \\
0.84(0.69-1.02) \\
0.59(0.47-0.73) \\
0.59(0.47-0.73) \\
0.81(0.64-1.02)\end{array}$ \\
\hline & L858R & $\begin{array}{c}\text { Overall } \\
\text { Reversible TKI (erlotinib, gefitinib) } \\
\text { Irreversible TKI (afatinib) } \\
\text { TKI vs cisplatin-based chemotherapy } \\
\text { TKI vs carbiplatin-based chemotherapy }\end{array}$ & $\begin{array}{l}5 \\
3 \\
2 \\
2 \\
2\end{array}$ & $\begin{array}{l}\text { Hazard ratio (IV, random, 95\% Cl) } \\
\text { Hazard ratio (IV, random, 95\% CI) } \\
\text { Hazard ratio (IV, random, 95\% Cl) } \\
\text { Hazard ratio (IV, random, 95\% CI) } \\
\text { Hazard ratio (IV, random, 95\% Cl) }\end{array}$ & $\begin{array}{l}1.15(0.95-1.39) \\
1.06(0.76-1.49) \\
1.25(0.99-1.60) \\
1.25(0.99-1.60) \\
1.09(0.69-1.90)\end{array}$ \\
\hline
\end{tabular}


compared with conventional chemotherapy. Future clinical trials should take exon 19 deletions and L858R as distinct disease entities and evaluate treatment efficacy separately.

\section{ACKNOWLEDGEMENTS}

We thank all the staff in the Evidence-Based Medicine Center, Chang-Gung Memorial Hospital, Chia-Yi, Taiwan.

\section{CONFLICT OF INTEREST}

The authors declare no conflict of interest.

\section{REFERENCES}

Chou TY, Chiu CH, Li LH, Hsiao CY, Tzen CY, Chang KT, Chen YM, Perng RP, Tsai SF, Tsai CM (2005) Mutation in the tyrosine kinase domain of epidermal growth factor receptor is a predictive and prognostic factor for gefitinib treatment in patients with non-small cell lung cancer. Clin Cancer Res 11: 3750-3757.

Cross DA, Ashton SE, Ghiorghiu S, Eberlein C, Nebhan CA, Spitzler PJ, Orme JP, Finlay MR, Ward RA, Mellor MJ, Hughes G, Rahi A, Jacobs VN, Red Brewer M, Ichihara E, Sun J, Jin H, Ballard P, Al-Kadhimi K, Rowlinson R, Klinowska T, Richmond GH, Cantarini M, Kim DW, Ranson MR, Pao W (2014) AZD9291, an irreversible EGFR TKI, overcomes T790M-mediated resistance to EGFR inhibitors in lung cancer. Cancer Discov 4(9): 1046-1061.

DerSimonian R, Laird N (1986) Meta-analysis in clinical trials. Controlled Clin Trials 7(3): 177-188.

Egger M, Davey Smith G, Schneider M, Minder C (1997) Bias in meta-analysis detected by a simple, graphical test. BMJ 315(7109): 629-634.

EURTAC (2013) Highlights of Prescribing Information. Available at http:// www.accessdata.fda.gov/drugsatfda_docs/label/2013/021743s018lbl.pdf (accessed on 20 October 2014).

Fukuoka M, Wu YL, Thongprasert S, Sunpaweravong P, Leong SS, Sriuranpon V, Chao TY, Nakagawa K, Chu DT, Saijo N, Duffield EL, Rukazenkov Y, Speake G, Jiang H, Armour AA, To KF, Yang JC, Mok TS (2011) Biomarker analyses and final overall survival results from a phase III, randomized, open-label, first-line study of gefitinib versus carboplatin/ paclitaxel in clinically selected patients with advanced non-small-cell lung cancer in Asia (IPASS). J Clin Oncol 29: 2866-2874.

Furuyama K, Harada T, Iwama E, Shiraishi Y, Okamura K, Ijichi K, Fujii A, Ota K, Wang S, Li H, Takayama K, Giaccone G, Nakanishi Y (2013) Sensitivity and kinase activity of epidermal growth factor receptor (EGFR) exon 19 and others to EGFR-tyrosine kinase inhibitors. Cancer Sci 104(5): 584-589.

GLOBOCAN (2008) Country Fast Stat. Available at http://globocan.iarc.fr./ factsheet.asp (accessed on 7 November 2014).

Gao G, Ren S, Li A, Xu J, Xu Q, Su C, Gou J, Deng Q, Zhou C (2012) Epidermal growth factor receptor-tyrosine kinase inhibitor therapy is effective as first-line treatment of advanced non-small-cell lung cancer with mutated EGFR: a meta-analysis from six phase III randomized controlled trials. Int J Cancer 131(5): E822-E829.

Higgins JP, Thompson SG (2002) Quantifying heterogeneity in a metaanalysis. Stat Med 21(11): 1539-1558.

Higgins JP, Thompson SG, Deeks JJ, Altman DG (2003) Measuring inconsistency in meta-analyses. BMJ 327(7414): 557-560.

Higgins JP, Green S eds. (2008) Cochrane collaboration. Cochrane Handbook for Systematic Reviews of Interventions. John Wiley \& Sons: West Sussex, England.

Hirsch FR, Bunn PA Jr (2009) EGFR testing in lung cancer is ready for prime time. Lancet Oncol 10(5): 432-433.

Hata A, Yoshioka H, Fujita S, Kunimasa K, Kaji R, Imai Y, Tomii K, Iwasaku M, Nishiyama A, Ishida T, Katakami N (2010) Complex mutations in the epidermal growth factor receptor gene in non-small cell lung cancer. J Thorac Oncol 5: 1524-1528.

Han JY, Park K, Kim SW, Lee DH, Kim HY, Kim HT, Ahn MJ, Yun JS, Suh C Yoon SJ, Han JH, Lee JW, Jo SJ, Lee JS (2012) First-SIGNAL: first-line single-agent iressa versus gemcitabine and cisplatin trial in never smokers with adenocarcinoma of the lung. J Clin Oncol 30(10): 1122-1128.

Haaland B, Tan PS, de Castro Jr G, Lopes G (2014) Meta-analysis of first-line therapies in advanced non-small-cell lung cancer harboring EGFR-activating mutations. J Thorac Oncol 9(6): 805-811.

Inoue A, Kobayashi K, Maemondo M, Sugawara S, Oizumi S, Isobe $\mathrm{H}$, Gemma A, Harada M, Yoshizama H, Kinoshita I, Fujita Y, Okinaga S, Hirano H, Yoshimori K, Harada T, Saijo Y, Hagiwara K, Morita S, Nukiwa T. North-East Japan Study Group (2013) Updated overall survival results from a randomized phase III trial comparing gefitinib with carboplatin-paclitaxel for chemo-naive non-small cell lung cancer with sensitive EGFR gene mutations (NEJ002). Ann Oncol 24: 54-59.

Ichihara E, Hotta K, Nogami N, KuyamaS, Kishino D, Fujii M, Kozuki T, Tabata M, Harada D, Chikamori K, Aoe K, Ueoka H, Hosokawa S, Bessho A, Hisamoto-Sato A, Kubo T, Oze I, Takigawa N, Tanimoto M, Kiura K (2015) Phase II trial of gefitinib in combination with bevacizumab as first line therapy for advanced non-small-cell lung cancer with activating EGFR gene mutations: the Okayama Lung Cancer Study Group Trial 1001. J Thorac Oncol 10(3): 486-491.

Kosaka T, Yamaki E, Mogi A, Kuwano H (2011) Mechanisms of resistance to EGFR TKIs and development of a new generation of drugs in non-smallcell lung cancer. J Biomed Biotechonol 2011: 165214.

Katakami N, Morita S, Yoshioka H, Seto T, Urata Y, Satouchi M, Iwamoto Y, Otsuka K, Ikeda N, Takahashi T, Daga H, Oguri T, Goto I, Uchida J, Sugawara S, Kitagawa C, Kozuki T, Inata J, Nakagawa K, Nakanishi Y (2014) Randomized phase III study comparing gefitinib with erlotinib in patients with previously treated advanced lung adenocarcinoma. J Clin Oncol 32(Suppl): abstr 8041.

Kato T, Seto T, Nishio M, Goto K, Atagi S, Hosomi Y, Yamamoto N, Hida T, Maemondo M, Nakagawa K, Nagase S, Okamoto I, Yamanaka T, Harada R, Fukuoka M, Yamamoto N (2014) Erlotinib plus bevacizumab (EB) versus erlotinib alone (E) as first-line treatment for advanced EGFR mutation-positive non-squamous non-small cell lung cancer (NSCLC): an open-label randomized trial. J Clin Oncol 32: abstract 8005.

Lynch TJ, Bell DW, Sordella R, Gurubhagavatula S, Okimoto RA, Brannigan BW, Harris PL, Haserlat SM, Supko JG, Haluska FG, Louis DN, Christiani DC, Settelman J, Haber DA (2004) Activating mutations in the epidermal growth factor receptor underlying responsiveness of non-smallcell lung cancer to gefitinib. N Eng J Med 350(21): 2129-2139.

Li D, Ambrogio L, Shimamura T, Shimamura T, Kubo S, Takahashi M, Chirieac LR, Padera RF, Shapiro GI, Baum A, Himmelsbach F, Retting WJ, Meyerson M, Solca F, Greulich H, Wong KK (2008) BIBW2992, an irreversible EGFR/HER2 inhibitor highly effective in preclinical lung cancer models. Oncogene 27(34): 4702-4711.

Lee CK, Brown C, Gralla RJ, Hirsh V, Thongprasert S, Tsai CM, Tan EH, Ho JC, Chu da T, Zaatar A, Osorio Sanchez JA, Vu VV, Au JS, Inoue A, Lee SM, Gebski V, Yang JC (2013) Impact of EGFR inhibitor in non-small cell lung cancer on progression-free and overall survival: a meta-analysis. J Natl Cancer Inst 105(9): 595-605.

Liang W, Wu X, Fang W, Zhao Y, Yang Y, Hu Z, Xue C, Zhang J, May Y, Zhou T, Yan Y, Hou X, Qin T, Dinglin X, Tian Y, Huang P, Huang Y, Zhao H, Zhang L (2014) Network meta-analysis of erlotinib, gefitinib, afatinib, and icotinib in patients with advanced non-small-cell lung cancer harboring EGFR mutations. PLoS One 9(2): e85245.

Lu RL, Hu CP, Yang HP, Li YY, Gu QH, Wu L (2014) Biological characteristics and epidermal growth factor receptor tyrosine kinase inhibitors efficacy of EGFR mutation and its subtypes in lung adenocarcinoma. Patho Oncol Res 20: 445-451.

Mitsudomi T, Yatabe Y (2007) Mutations of the epidermal growth factor receptor gene and related genes as determinants of epidermal growth factor receptor tyrosine kinase inhibitors sensitivity in lung cancer. Cancer Sci 98: 1817-1824.

Mok TS, Wu YL, Thongprasert S, Yang CH, Chu DT, Saijo N, Sunpaweravong P, Han B, Margono B, Ichinose Y, Nishiwaki Y, Ohe Y, Yang JJ, Chewaskulyoung B, Jiang H, Duffield EL, Watkins CL, Armour AA, Fukuoka M (2009) Gefitinib or carboplatin-paclitaxel in pulmonary adenocarcinoma. N Eng J Med 361(10): 947-957.

Maemondo M, Inoue A, Kobayashi K, Sugawara S, Oizumi S, Isobe H, Gemma A, Harada M, Yoshizama H, Kinoshita I, Fujita Y, Okinaga S, Hirano H, Yoshimori K, Harada T, Ogura T, Ando M, Miyazawa H, Tanaka T, Saijo Y, Hagiwara K, Morita S, Nukiwa T. North-East Japan Study Group (2010) Gefitinib or chemotherapy for non-small-cell lung cancer with mutated EGFR. N Eng J Med 362(25): 2380-2388. 
Mitsudomi T, Morita S, Yatabe Y, Negoro S, Okamoto I, Seto T, Satouchi M, Tada H, Hirashima T, Asami K, Katakami N, Takada M, Yoshioka H, Shibata K, Kudoh S, Shimizu E, Saito H, Toyooka S, Nakagawa K, Fukouka M. West Japan Oncology Group (2010) Gefitinib versus cisplatin plus docetaxel in patients with non-small-cell lung cancer harbouring mutations of the epidermal growth factor receptor (WJTOG3405): an open label, randomised phase 3 trial. Lancet Oncol 11(2): 121-128.

Mitsudomi T, Morita S, Yatabe Y, Negoro S, Okamoto I, Seto T, Satouchi M, Tada H, Hirashima T, Asami K, Katakami N, Takada M, Yoshioka H, Shibata K, Kudoh S, Shimizu E, Saito H, Toyooka S, Nakagawa K, Fukouka M (2012) Updated overall survival results of WJTOG 3405, a randomized phase III trial comparing gefitinib $(\mathrm{G})$ with cisplatin plus docetaxel $(\mathrm{CD})$ as the first-line treatment for patients with non-small cell lung cancer harboring mutations of the epidermal growth factor receptor (EGFR). J Clin Oncol 30(Suppl): abstract 7521.

Oxnard GR, Arcila ME, Sima CS, Riely GJ, Chmielecki J, Kris MG, Pao W, Ladanyi M, Miller VA (2011) Acquired resistance to EGFR tyrosine kinase inhibitors in EGFR-mutant lung cancer: distinct natural history of patients with tumors harboring the T790M mutation. Clin Cancer Res 15(17): 1616-1622.

Paez JG, Jänne PA, Lee JC, Tracy S, Greulich H, Gabriel S, Herma P, Kaye FJ, Linderman N, Boggon TJ, Naoki K, Sasaki H, Fujii Y, Eck MJ, Sellers WR, Johnson BE, Meyerson M (2004) EGFR mutations in lung cancer: correlation with clinical response to gefitinib therapy. Science 304(5676): 1497-1500.

Paz-Ares L, Soulières D, Moecks J, Bara I, Mok T, Klughammer B (2014) Pooled analysis of clinical outcome for EGFR TKI-treated patients with EGFR mutation-positive NSCLC. J Cell Mol Med 18(8): 1519-1539.

Review Manager (2014) [Computer program]. Version 5.3. Copenhagen: The Nordic Cochrane Centre, The Cochrane Collaboration.

Rosell R, Carcereny E, Gervais R, Vergnenegre A, Massuti B, Felip E, Palmero R, Garcia-Gomez R, Pallares C, Sanchez JM, Porta R, Coho M, Garrido P, Longo F, Moran T, Insa A, De Marinis F, Corre R, Bover I, Illiano A, Dansin E, de Castro J, Milella M, Reguart N, Altavilla G, Jimenez U, Provencio M, Moreno MA, Terrasa J, Muñoz-Langa J, Valdivia J, Isla D, Domine M, Molinier O, Mazieres J, Baize N, Garcia-Campelo R, Robinet G, Rodriguez-Abreu D, Lopez-Vivanco G, Gebbia V, Ferrera-Delgado L, Bombaron P, Bernabe R, Bearz A, Artal A, Cortesi E, Rolfo C, Sanchez-Ronco M, Drozdowskyj A, Queralt C, de Aguirre I, Ramirez JL, Sanchez JJ, Molina MA, Taron M, Paz-Ares L. Spanish Lung Cancer Group in collaboration with Groupe Français de Pneumo-Cancérologie and Associazione Italiana Oncologia Toracica (2012) Erlotinib versus standard chemotherapy as first-line treatment for European patients with advanced EGFR mutation-positive non-small-cell lung cancer (EURTAC). Lancet Oncol 13(3): 239-246.

Sharma SV, Bell DW, Settleman J, Haber DA (2007) Epidermal growth factor receptor mutations in lung cancer. Nat Rev Cancer 7(3): 169-181.

Scagliotti GV, Parikh P, von Pawel J, Biesma B, Vansteenkiste J, Manegold C, Serwatowski P, Gatzemeier U, Digumarti R, Zukin M, Lee JS, Mellemgaard A, Park K, Patil S, Rolski J, Goksel T, de Marinis F, Simms L, Sugarman KP, Gandara D (2008) Phase III study comparing cisplatin plus gemcitabine with cisplatin plus pemetrexed in chemotherapy-naive patients with advancedstage non-small-cell lung cancer. J Clin Oncol 26: 3543-3551.

Sekine A, Kato T, Hagiwara E, Shinohara T, Komagata T, Iwasawa T, Satoh H, Tamura K, Kasamatsu T, Hayashihara K, Saito T, Takahashi H, Ogura T (2012) Metastatic brain tumors from non-small-cell lung cancer with EGFR mutations: distinguishing influence of exon 19 deletion on radiographic features. Lung Cancer 77(1): 64-69.

Sequist LV, Yang JC, Yamamoto N, O’Byrne K, Hirsh V, Mok T, Geater SL, Orlov S, Tsai CM, Boyer M, Su WC, Bennouna J, Kato T, Gorbunova V, Lee VH, Shah R, Massey D, Zazulina V, Shahidi M, Schuler M (2013) Phase III study of afatinib or cisplatin plus pemetrexed in patients with metastatic lung adenocarcinoma with EGFR mutations. J Clin Oncol 31(27): 3327-3334.

Sebastian M, Schmittel A, Reck M (2014) First-line treatment of EGFRmutated non-small cell lung cancer: critical review on study methodology. Eur Respir Rev 23(131): 92-105.

Skrickova J, Bortlicek Z, Hejduk K, Pesek M, Kolek V, Koubkova L, Tomiskova M, Roubec J, Havel L, Salajka F (2014) The results of gefitinib in front-line treatment of Caucasian patients with NSCLC in the Czech
Republic: analysis according to activated mutations location. Transl Lung Cancer Res 3(5): AB010.

Wu JY, Wu SG, Yang CH, Gow CH, Chang YL, Yu CJ, Shih JY, Yang PC (2008) Lung cancer with epidermal growth factor receptor exon 20 mutations is associated with poor gefitinib treatment response. Clin Cancer Res 14: 4877-4882.

Wu Y, Liam C, Zhou C, Wu G, Liu X, Zhong Z, Lu S, Cheng Y, Han B, Chen L, Zhu Y, Qin S, Huang C, Pan H, Liang H, Li E, How SH, Jiang G, Fernando MC, Chen M, Zuo Y, Ladrera G (2013) First-line erlotinib versus cisplatin/gemcitabine (GP) in patients with advanced EGFR mutation-positive non-small-cell lung cancer (NSCLC): interim analyses from the phase 3, open-label, ENSURE study. J Thoracic Oncol 8(Suppl 2): S603.

Wang H, Huang J, Yu X, Han S, Yan X, Sun S, Zhu X (2014) Different efficacy of EGFR tyrosine kinase inhibitors and prognosis in patients with subtypes of EGFR-mutated advanced non-small cell lung cancer: a meta-analysis. J Cancer Res Clin Oncol 140(11): 1901-1909.

Wu YL, Zhou C, Hu CP, Feng J, Lu S, Huang Y, Li W, Hou M, Shi JH, Lee KY, Xu CR, Massey D, Kim M, Shi Y, Geater SL (2014) Afatinib versus cisplatin plus gemcitabine for first-line treatment of Asian patients with advanced non-small-cell lung cancer harbouring EGFR mutations (LUX-lung 6): an open label, randomised phase 3 trial. Lancet Oncol 15(2): 213-222.

Yoshida T, Yamada K, Azuma K, Kawahara A, Abe H, Hattori S, Yamashita F, Zaizen Y, Kage M, Hoshino T (2013) Comparison of adverse events and efficacy between gefitinib and erlotinib in patients with non-small-cell lung cancer: a retrospective analysis. Med Oncol 30(1): 349.

Yang JC, Sequist LV, Schuler M, Mok T, Yamamoto N, O’Byrne K, Hirsh V, Geater SL, Zhou C, Massey D, Zazulina V, Wu YL (2014) Overall survival in patients with advanced non-small cell lung cancer harboring common (Del19/L858R) epidermal growth factor receptor mutations: pooled analysis of two large open-label phase III studies (LUX-lung 3 and LUX-lung 6) comparing afatinib with chemotherapy. J Clin Oncol 32(suppl): abstract 8004 .

Yang JC, Wu YL, Schuler M, Sebastian M, Popat S, Yamamoto N, Zhou X, Hu CP, O’Byrne K, Feng J, Lu S, Huang Y, Geater SL, Lee KY, Tsai CM, Gorbunova V, Hirsh V, Bennouna J, Orlov S, Mok T, Boyer M, Su WC, Lee KH, Kato T, Massey D, Shahidi M, Zazulina V, Sequist LV (2015) Afatinib versus cisplatin-based chemotherapy for EGFR mutation-positive lung adenocarcinoma (LUX-lung 3 and LUX-lung 6): analysis of overall survival data from two randomized, phase 3 trials. Lancet Oncol 16(2): 141-151.

Zhou C, Wu YL, Chen G, Feng J, Liu XQ, Wang C, Zhang S, Wang J, Zhou S, Ren S, Lu S, Zhang L, Hu C, Lou Y, Chen L, Ye M, Huang J, Zhi X, Zhang Y, Xiu Q, Ma J, Zhang L, You C (2011) Erlotinib versus chemotherapy as first-line treatment for patients with advanced EGFR mutation-positive non-small-cell lung cancer (OPTIMAL, CTONG0802): a multi-centre, open-label, randomised, phase 3 study. Lancet Oncol 12(8): 735-742.

Zhou C, Wu Y, Liu XQ, Wang C, Chen G, FENG J, Zhang S, Wang J, Zhou S, Ren S, Lu S, Zhang L, Hu C, Lou Y, Chen L, Ye M, Huang J, Zhi X, Zhang Y, Xiu Q (2012) Overall survival (OS) results from OPTIMAL (CTONG0802), a phase III trial of erlotinib (E) versus carboplatin plus gemcitabine (GC) as first-line treatment for Chinese patients with EGFR mutation-positive advanced non-small cell lung cancer (NSCLC). J Clin Oncol 30(Suppl): abstract 485s.

Zeng Z, Yan HH, Zhang XC, Zhong WZ, He YY, Guan JL, Niu FY, Xie Z, Huang YS, Xu CR, Dong S, Wu YL (2014) Reduced chemotherapy sensitivity in EGFR-mutant lung cancer patient with frontline tyrosine kinase inhibitor. Lung Cancer 86: 219-224.

Zhang Y, Sheng J, Kang S, Fang W, Yan Y, Hu Z, Hong S, Wu X, Qin T, Liang W, Zhang L (2014) Patients with exon 19 deletion were associated with longer progression-free survival compared to those with L858R mutation after first-line EGFR-TKIs for advanced non-small cell lung cancer: a meta-analysis. PLoS One 9(9): e107161.

This work is published under the standard license to publish agreement. After 12 months the work will become freely available and the license terms will switch to a Creative Commons AttributionNonCommercial-Share Alike 4.0 Unported License. 